\title{
Positioning in cyberspace: Evaluating bestselling authors' online communicated brand personalities using computer-aided content analysis
}

\author{
R.A. Opoku \\ Assistant Professor of Marketing, \\ Department of Management and Marketing, \\ King Fahd University of Petroleum and Minerals \\ opoku@kfupm.edu.sa \\ L.F. Pitt \\ Faculty of Business Administration, Simon Fraser University, \\ 8888 University Drive, Burnaby, BC, Canada V5A 1S6 \\ lpitt@sfu.ca \\ R. Abratt* \\ University of the Witwatersrand, Johannesburg, and \\ Huizenga School of Business and Entrepreneurship, \\ Nova Southeastern University, 3301 College Avenue, \\ Ft. Lauderdale, F133314, USA \\ abratt@huizenga nova.edu \\ Received September 2007-
}

\begin{abstract}
This study employs a computer-aided text analysis technique to explore whether bestselling authors communicate Aaker's brand personality in the online environment. We argue that content analysis facilitated by a computer is relatively reliable and less tedious than that performed by human coders. We analyse the content of websites on the presumption that this reflects what the author wants to say about him/herself. The study offers a new technique for content analysts and marketing communicators to quantify various aspects of marketing communications and goes a little further towards the evaluation and mapping of websites using correspondence analysis.
\end{abstract}

*To whom all correspondence should be addressed.

\section{Introduction}

The huge increase in the number of books being published has created much choice that makes it difficult for most books to be promoted and displayed prominently. In an overcommunicated society, authors and publishers continually strive for more effective ways to communicate their message to consumers. After examining the works of two dozen writers, Auchincloss (2005) suggests that great art flows from the expression of an author's unique personality. Given the tremendous sales of bestselling novels, the reading of these books must create a loyal readership and following amongst well known authors. One can therefore treat authors as a brand. We suggest that authors of best-selling novels have a personality that differentiates themselves from others. This differentiation is critical for the following reasons. Firstly, authors can identify and work on their personalities among potential readers, which can lead to increased book sales, value and bargaining power with publishers. Secondly, in order to make their works more attractive to a broader target market, authors often need to assess and modify their brand personality to suit their markets in order to leverage their existing brand image.
In this paper we concentrate on how a brand personality is communicated by means of websites because most of the studies on bestsellers and major motion pictures are limited to magazines, periodicals; general release films and adultonly paper fiction (Abrahamson \& Mechanic, 1983). Website communication is relatively new and therefore this medium may also provide a new perspective. In contextualizing this study and taking into consideration Aaker's (1997, p.347) definition, brand personality is viewed as "the set of human characteristics associated with a particular bestselling author and how these are communicated through their personal websites in order to aid him/her to position him/herself among its competitors." In many respects, content analysis has served as an important and powerful tool in determining authorship. For instance, Mosteller and Wallace (1964) used Bayesian techniques based on word frequency to show that Madison was indeed the author of the Federalist Papers. Foster (1996) also used the stylometric data (numerical measures of word usage and grammatical constructions) in order to determine the identity of the anonymous author of the 1992 political novel, Primary Colors, a charge the original author denied until confronted by the Washington Post with editorial corrections in his handwriting. All these were done 
by compiling a list of suspected authors, examine their prior writings, and the correlation of the frequency of nouns or function words to help build a case for the probability of each person's authorship of the data of interest (Stemler, 2001).

The computer revolution has brought in this wake the proliferation of content analytic methodologies in research. By using a computerised context analysis as a methodology, this study illustrates a relatively simple but powerful tool for analysing words. The text selected for analysis in this study is the lexical information provide on 10 websites of bestselling authors. Our aim is not provide an extensive review of a theory but rather to outline how to isolate and quantify some of the broad themes of brand personality by extending prior studies in this area. As it is usual, though not mandatory in content analysis to derive the words or themes to be measured from some prior theory (Weber, 1985), we chose Aaker's (1997) brand personality dimensions as a measurement due to its wide applicability (see Ferrandi et al., 2000; Aaker et al., 2001; Davies et al., 2001; Opoku, 2005). Whilst overcoming one of the methodological concerns of content analysis-namely, that of developing an accurate and reliable coding process (Kassarjian, 1977; Kolbe \& Burnett, 1991), we also illustrate that computerized text analysis is critical because of its importance in quantifying and presenting various aspects of marketing communication with ease and to help researchers make a better informed decision.

In order to provide and strengthen a context for our analysis, we briefly review the literature by setting it out as follows: firstly, we examine the literature on bestselling novels. Secondly, we look at content analysis as a tool in qualitative research. Thirdly, on the basis of a multistage research methodology, we develop and illustrate a relatively simple but powerful tool to examine the brand personality of individuals and organisations. Fourthly, we present and discuss the implications of our findings to theory, authors, publishers and brand managers and suggestion future research in this area.

\section{Bestsellers' authors as brands}

Research on bestsellers is not new. A stream of literature has dealt with the mood and attitude of those who chose to read these bestselling novels (Hart, 1950) and as to what they think and want (Cockburn, 1972). Others have concentrated on the content of novels in an attempt to isolate content characteristics by differentiating bestsellers from similar novels which failed to sell so well (Harvey, 1953); have noted how these bestsellers express and feed certain needs in the reading public (Sutherland, 1981) and reflection of the social and personal attitudes that characterise a particular period (Mullins \& Kopelman (1984). Another stream of literature has sought to deal with the expression of sexuality in best-selling novels. Some authors have found that bestselling novels and major motion pictures exist as a primary source of sexual information (Abrahamson \& Mechanic, 1983); readers and non readers of erotic romances have different motives for reading recreational books (Coles \& Shamp,1984) and as a component of popular culture and an instrument for societal analysis (Greene, 1980). In all of these, Brown (2004) argued that there is more to outstanding writing than many suppose. It's not simply a matter of short sentences, plain prose and setting out the facts succinctly. For instance, Auchincloss (2005) considers the inextricable link between a writer's personality and the fiction he or she creates.

Although the concept of brand and brand personality did not exist then, it is clear that non- contemporary authors and literary greats who produced bestsellers of their times such as Shakespeare, Hemingway, Goethe, Dickens, Twain, Chaucer, Cervantes, Dante, Wilde and Montaigne were definitely seen as representing certain values and personalities and indeed guaranteeing a calibre of product that their readers rely on. Authors become brands if they write in a certain way. In most situations, readers' minds are captured and "locked-in" to read books from certain authors because they know what they are going to get. By the nature of author's craft, readers presume that they will get a continuation of the same style from the earlier novel or not to get something wildly different from the earlier work. As a result of this motivation and readers' consumption behaviour, authors build up a brand personality which further leads to brand loyalty amongst readers and ultimately their books become bestsellers. Most studies to date have focused on the content of novels and how they affect the social and personal attitudes of the readers. There have been surprisingly few studies of bestselling authors, hence their failure to sometimes address the personality of the author whose imaginations form part of their work.

\section{Content analysis}

Content analysis is a method of codifying a text (or content) of a piece of writing into various groups (or categories) depending on the selected criteria (Weber, 1988) and by objectively and systematically identifying specified characteristics of messages (Stone et al., 1966). The content may include words, meanings, pictures, symbols, ideas, themes, or any message that can be communicated (Neuman, 2003). In simple terms, it is a technique for gathering and analyzing the content of a text. A plethora or research on content analysis in the marketing field has focused on searching for meaning in magazines (see Tse, Belk \& Zhou, 1989; Gross \& Sheth, 1989; Kolbe \& Burnett, 1991; Kolbe \& Albanese, 1996 television advertisement 1996) (Resnik \& Stern, 1977; Dowling, 1980) and bestselling books (Harvey, 1953; Mullins \& Kopelman, 1984; Abrahamson \& Mechanic, 1983) but it appears that few have focused on websites.

Cooper and Schindler (2003) noted that the breadth of content analysis makes it a flexible and wide-ranging tool that may be used as a general methodology or as a problemspecific technique. However, many authors have been silent on whether content analysis as a research strategy belongs to the qualitative or quantitative approach (Neuman, 2003). Some authors recognise it as quantitative (see Bryman \& Bell, 2003:194; Berelson, 1952) and others have positioned it squarely inside the qualitative domain (Miles \& Huberman, 1994; Boyle, 1994; Tesch, 1990). Still others have argued for its dynamic nature by indicating that it used to be quantitative but in modern times it is gaining currency 
as a qualitative approach (see Marshall \& Rossman, 1999; Cooper \& Schindler, 2003; Krippendorf, 2004). In questioning the validity and usefulness of the distinction between quantitative and qualitative content analysis, Krippendorf (2004:19) argued that 'all reading of texts is qualitative, even when certain characteristics of a text are later converted into numbers'. In this study however, we argue that computers can clearly be supportive, be it qualitative or quantitative content analysis by serving as a repository for coding data and provide power tools for analysing and reporting research.

After the popularization of General Inquirer content analysis program by Stone et al. (1966), computer-aided content analysis of texts has gained wider usage. Various computeraided text analyses has been performed and described in different studies. For some examples of its varied applications, see (Stone et al., 1966; Weber, 1985; Erdener \& Dun 1990; Wolfe, 1991; Kabanoff, 1996). Computer software programmes designed to facilitate this computeraided qualitative data analysis have proliferated over the past few years. This has brought in its wake various discussions on this subject matter (see special issue of Qualitative Sociology, Vol.7 (1-2), 1984). Using computers to facilitate qualitative data analysis has been given various names such as computer-assisted data analysis (see Maclaran and Catterall, 2002); computer-supported data analysis (see Romano et al., 2003) and computer-facilitated data analysis (see Wolfe et al., 1993

The contribution of computers to data analysis has been recognised in the following ways: 1) the management of textual data; 2) searching, retrieving and summarizing data; 3) linking qualitative and quantitative data; 4) articulating and codifying qualitative research methods; and 5) analyzing a number of rich sources of data, the analysis of which otherwise would be impractical (Wolfe et al., 1993), if not virtually impossible. Although such analysis is in theory possible without the aid of a computer, computer use augments analysis speed, power, memory, and ease of data access to overcome various challenges such as; voluminous data sets, complex of analyses, reviewing all details of the classification record, and providing flexibility and speed of analysis (Richards \& Richards,1987). Additionally, by facilitating iterative, systematic searches and by allowing the manipulation and display of text in various forms, computer-aided data analysis may allow one to perceive textual themes and patterns which might not otherwise be apparent (Wolfe et al., 1993).

While many programmes share common features, three general programme types may be distinguished: text retrieval, text analysis, and database manager programmes (Tesch, 1990). For this study, we were most interested in a text retrieval programme such as WordStat because they are designed to help answer questions concerning words, word categories, and concepts represented by key-words (Wolfe et al., 1993). In this study, the WordStat text-analysis program compares each word in website information collected with all the dictionary categories. Each time a word is identified; it is tagged and counted to a category. When all the words in a text document have been analysed, the author is profiled based on a set of frequency counts across the various dictionary categories.

\section{The concept of brand personality and its measurement}

According to Hogan (1991), the term 'personality' has had two completely different meanings throughout psychology's history as a discipline. The first connotation concerns an individual's internal processes and propensities and helps to explain why they act in a particular way; in this sense, personality is internal and must be inferred. In simple terms, this view of personality corresponds to a simple, 'what I say about myself'. The second meaning concerns one's social reputation or the manner in which a person is perceived by others, such as family, friends, co-workers and the public. In this sense, personality is public and verifiable; it is concerned with the amount of esteem, regard, and status accorded a person by outsiders. In this sense and in simple terms, personality has to do with 'What others say and think about me.'

The notion of brand personality results from the transfer of the personality concept from individual psychology to the marketing context. The assumption thereby is that brands, like individuals, can develop personalities that are indeed similar in their characteristics (Aaker, 1997). In this paper, we concentrate on how a brand personality is communicated by means of a website. In the literature, brand personality is often discussed with clear reference to product, corporate brands, or countries but not how this is communicated online.

There have been various attempts to develop measures of brand personality. Aaker (1997) proposes a 42 item Brand Personality Scale (BPS) that assesses any brand across five key dimensions: sincerity, excitement, competence, sophistication and ruggedness. Fournier's (1998) framework for understanding and extending brand personality utilizes a brand relationship quality model comprising six central factors, namely partners' quality, intimacy, interdependence, self-connection and love. Aaker's (1997) original scale, developed in the USA, was found to have some international applicability in subsequent work (Aaker, et al., 2001) in extensions conducted with Spanish and Japanese brands.

The dimensions of Aaker's Brand Personality Scale (BPS) are used in our study because they enable researchers to capture the symbolic meanings of brands as if they were people. Aaker's (1997) scale uses a list of adjectives that describe the most important personality differences between people from previous measures used in psychological and marketing research. The questionnaire can be presented to a group of respondents in their perceptions of a brand measured by considering the extent to which they believe it possesses the characteristics that comprise the BPS dimensions. However, in our study, as will be seen, we do not use customer perceptions as input to our determination of country brand personality. Rather, we use what is communicated on an author's website as input. Stated somewhat differently, we do not measure an author's brand personality by what others think it to be, but rather, what he or she says about itself. 


\section{Methodology}

This focus of this section is to describe the methodological approach used in the study.

\section{Sample selection and data source}

The sample was drawn from the combination of the Publisher's Weekly Longest-Running Bestsellers for fiction titles (hardcover category) and Top Sellers (in the paperback and mass market category) for 2005 and New York Times Bestsellers List for fiction books (hardcover category) for 2005. The sources of data were the 10 selected personal websites of bestselling authors shown in Table 1 .

Table 1: Original sample of the investigated official authors' websites

\begin{tabular}{l|l|c}
\hline Author & Website URL & $\begin{array}{l}\text { Number } \\
\text { Words }\end{array}$ \\
\hline Mitch Albom & http://www.albom.com/about_mitch htm & 17,974 \\
\hline Dan Brown & http://www.danbrown.com/ & 41,695 \\
\hline Tom Clancy & http://us.penguingroup.com/static/packages/us/tomclancy/ & 15,879 \\
\hline John Grisham & http://www randomhouse.com/features/grisham/main.php & 6,967 \\
\hline Stephen King & http://www.stephenking.com/index_flash.php & 39,542 \\
\hline Elizabeth Kostova & http://the-historian net/elizabethkostova html & 19,179 \\
\hline Sue Monk Kidd & http://www.suemonkkidd.com/default.asp & 41,786 \\
\hline James Patterson & http://www.jamespatterson.com/index.html & 20,420 \\
\hline Nicholas Sparks & http://www nicholassparks.com/index.php & 29,140 \\
\hline Danielle Steel & http://www.daniellesteel.com & 21,665 \\
\hline
\end{tabular}

We define our sample units of analysis to include not only the homepage but also the textual information derived from the homepage (initial screen) of each author and four levels down the hierarchy of information on its personal website. We initially copied all textual information from the homepage (the first page) into a text document. We then clicked all links and roots on the main portal and copied all information available into the same text document. This procedure was repeated in all the selected authors' websites. This rigid systematic procedure produces a considerable amount of textual information from each author's website In this study, we rely on words because the drift of computer supported-content analysis has been on the word as unit of analysis (Péladeau, 2003; Stone, 1997) rather than on sentences (Gottshalk, 1997) or semantic structures (Robert, 1989). Two major assumptions underlie the validity of counting word frequencies in brand personality communication. Firstly, it assumes that the language people use reflects what they are, intending to do, concerned with or focusing on. In our study, we assume that the words contained in these websites reflect what these authors think as well as what the important attributes or characteristics of themselves are. The second assumption is that the relative frequency with which particular words are used on a website is an indication of how the message sender is focusing on a particular brand personality dimension.

\section{Data collection}

For our data collection instrument, a comprehensive yet appropriate dictionary of terms was designed to collect and compile synonyms of Aaker's (1997) five brand personality dimensions. This was achieved with the help of the online version of Encyclopaedia Britannica's thesaurus function (www.britannica.com) by removing synonyms that were not appropriate in our circumstance. For instance, some synonyms of 'rugged' such as 'hairy' and 'rude' would not be useful for our purposes, and might distort results. Besides the thesaurus, the Dictionary Builder of the software package also suggested some related words that enriched the data collection tool. The foundation for the synonym collection was the set of personality traits presented by Aaker in her original article. In her article (1997:354), Aaker introduced a table with a set of 42 personality trait norms that she suggested should serve as an aid for comparing brand personalities across different categories. In this study, our aim was primarily to find original synonyms for all of these traits, as well as synonyms for the five basic dimensions, in order to enrich our data collection instrument. The five dimensions (which served as the dictionary categories) and their respective traits are:

- $\quad$ Sincerity (down-to-earth, honest, genuine, cheerful)

- $\quad$ Excitement (daring, spirited, imaginative, up-to-date)

- $\quad$ Competence (reliable, intelligent, successful)

- $\quad$ Sophistication (upper-class, charming)

- $\quad$ Ruggedness (tough, outdoorsy)

Two parallel lists of synonyms were collected in the same manner by two independent reviewers: one male and one female with multi-lingual backgrounds. These two lists thereafter were merged into one by selecting only those synonyms that had been identified by both independent reviewers. A third reviewer also independently appraised the draft dictionary and provided further comments and suggestions which were incorporated into the dictionary tool. These reviews were to further enhance the reliability of the instrument. This process generated a final list of 1625 words that were relatively and evenly distributed across Aaker's original five dimensions of brand personality as 
demonstrated by the following percentages: Sincerity $21 \%$ of all words listed; Excitement 17\%; Competence 20\%; Sophistication 21\%; and Ruggedness 21\%.

The next stage involved the converting of this list of synonyms into electronic format and categorizing them according to Aaker's brand personality dimensions through the WordStat software package. Recommended by Krippendorff (2004), this text retrieval computer-aided data analysis software is a text analysis module specifically designed to study textual information such as responses to open-ended questions, interviews, titles, journal articles, public speeches and electronic communications. With the help of the software's exclusion function, words with little semantic value such as pronouns and conjunctions were excluded from the dictionary whilst the stemming function of the software reduced various word forms to a more limited set of words based upon their roots. The stemming was done by remove or substitute common suffixes, for instance by converting plurals to singulars and reducing adjectives, verbs, and adverbs to a common noun or word stem. All these data reduction procedures are used because the presence of spurious variables causes a marked detrimental effect on the performance of most clustering methods (Punj and Steward, 1983).

After thoroughly pre-tested this newly-created automatic categorization dictionary, the textual information from the 10 authors' websites were converted into an analyzable format and imported into the computer-aided programme. (This dictionary is available on request from the authors). Following this, a content analysis was performed on these selected websites to find out how the brand personality dimensions were distributed.

\section{Data analysis}

Hoffman and Franke (1986) indicate that cross-tabulation of categorical data is perhaps the most commonly encountered and simple form of analysis in research. In relation to the Aaker's five brand personality dimensions, we provided a two-way contingency table of frequencies. This was obtained by aggregating the number of words identified by the analysis software. The distribution of these brand personalities over respective websites is presented in Table 2.

Table 2 Distribution of brand personality dimensions over websites

\begin{tabular}{|c|c|c|c|c|c|c|}
\hline $\begin{array}{l}\text { BPS Dimension/ } \\
\text { Author }\end{array}$ & Competence & Excitement & Ruggedness & Sincerity & Sophistication & Column Total \\
\hline Mitch Albom & 29 & 64 & 14 & 109 & 32 & 248 \\
\hline Dan Brown & 149 & 181 & 207 & 256 & 81 & 874 \\
\hline Tom Clancy & 72 & 139 & 86 & 105 & 12 & 414 \\
\hline John Grisham & 88 & 48 & 14 & 27 & 14 & 191 \\
\hline Stephen King & 271 & 196 & 69 & 252 & 39 & 827 \\
\hline Elizabeth Kostova & 73 & 110 & 35 & 180 & 46 & 444 \\
\hline Sue Monk Kidd & 72 & 210 & 82 & 517 & 194 & 1075 \\
\hline James Patterson & 74 & 155 & 34 & 115 & 41 & 419 \\
\hline Nicholas Sparks & 145 & 119 & 47 & 437 & 62 & 810 \\
\hline Danielle Steel & 93 & 198 & 60 & 206 & 78 & 635 \\
\hline Total Row & 1066 & 1420 & 648 & 2204 & 599 & 5937 \\
\hline Chi-square $\left(\chi^{2}\right)$ & 2412.60 & & & & & \\
\hline Degree of Freedom (df) & 36 & & & & & \\
\hline Probability Test & $\mathrm{p}<0.0001$ & & & & & \\
\hline NOTE: & \multicolumn{6}{|c|}{$\begin{array}{l}\text { For presentation purposes we have transposed rows and columns in this table. } \\
\text { In the analysis, what appear here as rows were columns, and vice versa }\end{array}$} \\
\hline
\end{tabular}

The cell counts in Table 2 reveal the number of times a particular brand personality dimension is associated with a particular author's website. The row and column marginal subtotals in this table indicate the number of mentions received by a particular dimension and website, respectively. In this table, it also can be ascertained that the Sue Monk Kidd website contained the most words associated with brand personality dimensions with 1075 terms whilst the John Grisham's website is least associated with 191 terms. With respect to individual dimensions, sincerity was the brand personality dimension portrayed most in all the authors' websites accounting for 37 percent (2204/59372) of the total words, whilst sophistication representing 10 percent was the least portrayed. A chisquare test $(\chi 2=2412.60 ; \mathrm{df}=36 ; \mathrm{p}<0.0001)$ shows that the row (i.e. the brand personality dimensions) and the column (i.e. websites) variables are related.

To reflect the relative descriptive power of the personality dimensions, we also computed the eigenvalues and also determined the dimensionality of our solution. Greenacre (1984) and Bendixen (1995) hinted these issues must be examined. Berthon et al. (1997) caution that finding a lower dimensional representation of the table, preferably two or at most three dimensions will help provide an 'adequate' summary of results. Most researchers such as Bendixen (1995), Hair, Anderson, Tatham and Black (1998) and Greenacre (1984) also agree that a two-way dimensional solution is preferable due to its ease of display and interpretability and helps to avoid the problem of interpreting inter-spatial distances. We therefore opted for a 
two-way dimensional correspondence analysis plot which accounts for 81 percent of the total variance, with eigenvalues and explained proportions of 0.080 and 0.53 for the first dimension, and 0.043 and 0.280 for the second dimensions respectively (see Appendix I for further details).

To enable us identify the associations between the websites and the brand personality dimensions with ease, we performed a correspondence analysis from the data, with the aid of the WordStat software. Correspondence analysis is a mapping technique. It cross-tabulates data and converts them into a joint space map by using the chi-square value for each cell (Bendixen, 1995). This technique is not new in the area of perceptual map construction (Greenacre, 1984; Lebart et al., 1984; Hoffman \& Franke, 1986; Hair et al., 1998) or in the clustering of brands (Bendixen, 1995; Hair et al., 1998). The perceptual map created through correspondence analysis is useful in uncovering structural relationships between different variables (Inman et al., 2004) and its graphic nature facilitates interpretation of data that otherwise would be difficult to comprehend (O'Brien, 1993). Moreover, Hair et al. (1998) state that correspondence analysis is best suited for exploratory data analysis. Since our study is exploratory in nature, our extension of our content analysis to correspondence analysis to this end seemed fitting. The output of the correspondence analysis procedure is depicted in Figure 1.

The map reveals the underlying structure and positioning of the investigated websites in relation to the brand personality dimensions. The graphical output also provides information about how the websites and dimensions are positioned in relation to each other.

\section{Results}

Our initial aim here was to identify the clear groupings by describing the map in terms of known characteristics. With this map, five clear groupings could be identified. The first group consists of Albom, Kostova and Sparks's official websites. Situated in the lower-left quadrant of the map, they seem to identify themselves with the sincerity dimension. The second group is made up of one website, Kidd's clustering close to sophistication dimension. The third group is made up of Patterson and Steel's websites. They are clustered close to the excitement dimension in the middle of the figure. Found in the upper-right quadrant of the figure, the fourth group is made of Brown and Clancy's websites. They tend to be getting closer to the ruggedness dimension. The last group consists of King and Grisham's websites. They can be located with the sincerity dimension in the lower-right quadrant of the map. Figure 1 also gives an indication of how the different brand personality dimensions relate to each other. Ruggedness and excitement are found in the same quadrant, and the other three dimensions stand alone in their respective quadrant.

Secondly, the distances between the row and column variables were interpreted. However, Hoffman and Franke (1986) noted that, as the distances between the row and column variables cannot be specifically interpreted, one also should exercise some caution when analyzing a perceptual map. This is due to the fact that the columns and rows are scaled independently. The implication is that, just because a certain website is positioned near a certain brand personality dimension does not necessarily mean that the site and dimension are closely related. Conversely, the angle between the words and websites does portray a meaning in this regard. Thus, an acute angle indicates that two characteristics are positively correlated, whereas an obtuse angle indicates negative correlation (Lebart et al., 1998). For example, although Mitch Albom's website graphically appears to be more closely related to sincerity than Elizabeth Kostova's website, the latter should be identified as possessing more of this dimension since it is situated at a steeper angle.

Again, as the between-set distances cannot be interpreted strictly in our circumstances, a web site tends towards a position in its space that corresponds to the dimensions that are the most prominent in its profile. In other words, the specific distances between the websites and the brand personality dimensions should not only be interpreted, but the ordinal proximity of particular web sites to certain dimensions may have meaning. Thus, in this study we also rely on the category positions from the correspondence analysis rather than the distances from particular dimensions. It can therefore be deduced from the map that the authors are clustered near to the brand personality dimension that they mostly communicate in their websites. For example, competence in the case of Stephen King, and the reverse for Dan Brown in relation to the same dimension. If an author's official website is not close to any of the dimensions, then it is not communicating a strong brand personality on any of the dimensions. If an author falls in between or among the dimensions the case could either be that his/her message is mainly spilt between two or more dimensions, or that it is not clear what is been communicated.

\section{Discussion of results}

The perceptual map generated by means of correspondence analysis indicates that the official website of Albom, Kostova and Sparks primarily convey the dimension of sincerity. Sparks' website is located at a rather skewed angle indicating a weaker correspondence and in relative terms, it is the farthest from this dimension. Albom, among all the authors, has been closely associated with its chosen personality dimension; and we can note its immediate proximity to the dimension on the correspondence analysis map. Patterson and Steel align themselves with excitement. Kidd appears to be communicating the brand personality dimension of sophistication but have an element of sincerity. Again, comparing King to all the authors, none of them communicates competence strongly as him, as is evident from their various positions in relation to this dimension on the map. 


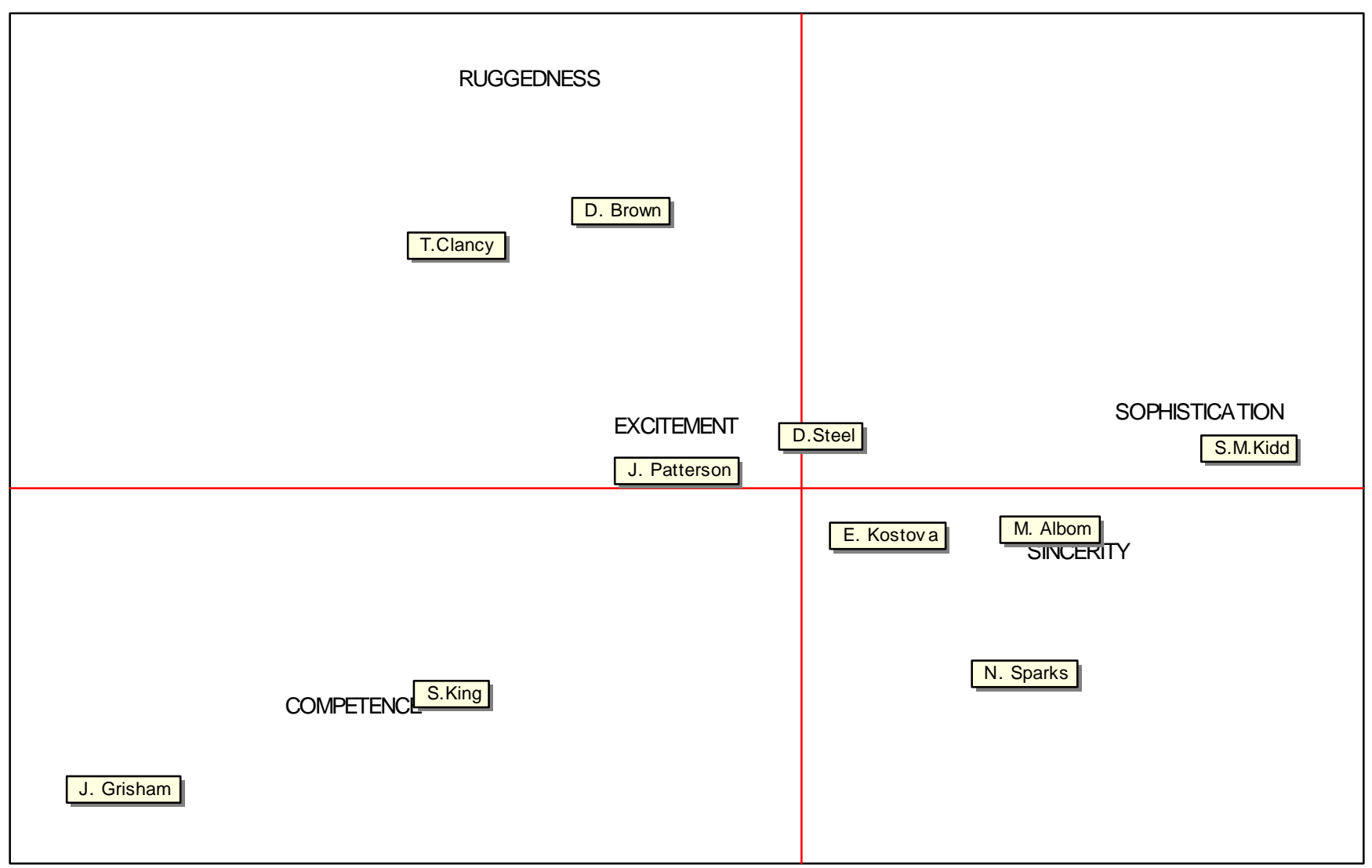

Figure 1. Correspondence analysis map of 10 bestselling authors' official websites in relation to the five brand personality dimensions

A second look at the content of these authors' official websites will support this summary to be reasonably accurate and representative. Veteran and prolific authors like Stephen King and John Grisham appear to focus upon competence although the former message is stronger than the latter. Both exhibit their competence in the form of experience. King's works date back as far as 1959. His books have been enormously successful, and are often featured on bestseller lists. His competence among others has been clearly demonstrated in one of his numerous books called On Writing. As an experience writer, he offered great advice based upon his experience and he not only shows that it is possible to become a great writer, but King also shows writers that nothing ever comes easily without hard work and was the 2003 recipient of the Lifetime Achievement Award by the National Book Award. John Grisham also demonstrates his competence in the form of his experience in producing bestsellers. Publishers Weekly declared Grisham "the bestselling novelist of the 1990s". His 1992 novel, The Pelican Brief sold 11,232,480 copies in the United States alone, making it the bestselling novel of the decade and the only novel to sell ten million copies or more during the decade.

The official websites of Patterson and Steel also communicate the brand personality dimension of excitement. Both presume to exhibit their excitement in their respective writings. Patterson demonstrates this dimension in his unique ability to master different genres by creating both exciting and mystery stories for children and youth and detective series for adults. In 2005 alone, James Patterson had five consecutive \#1 New York Times bestselling hardcover novels-a record held by no other author. Patterson captured the minds of young and older readers alike in 2005 by delving into the world of flight and fantasy with his firstever series for teens, Maximum Ride. Hollywood has begun to recognize the power of James Patterson's stories after the success of Paramount's Two Alex Cross movies (Kiss the Girls and Along Came a Spider). Best known for her romance novels, as of 2005, Danielle Steel's message on excitement could presumably be embedded in her style of writing by maintaining several twists and surprises to keep the interest of her readers throughout the book. Some of her books such as Heartbeat have been acclaimed by Contemporary Popular Writers and Washington Post to be very entertaining.

Albom, Kostova and Sparks' websites manifest the brand personality of sincerity. Albom seems to do this well but Sparks appears not to be communicating his message on this dimension very clearly. Mitch Albom is the author of eight books, including the New York Times bestseller 'The Five People You Meet in Heaven', and the phenomenal bestseller 'Tuesdays with Morrie.' He is engaged in other journalist jobs. This had put him at the center of a journalistic controversy in April 2005 concerning a game resulting in the call for his resignation as a columnist. It is possible that this author would like to correct his image by positioning himself closest to this dimension. Born as Elizabeth Johnston and with a natural flair for storytelling, Elizabeth 
Kostova demonstrates her sense of sincerity by the way she attaches importance to history and the present by blending fact and fantasy in equal measures. She tried never to forget that history is also a series of human experiences, which can be conveyed in an academic way but can also be told as stories in the classic sense. Like all good historical fiction, the success of Kostova's book, The Historian begins with her choice of a subject matter so captivating in its own truth that it stands alone. Nicholas Sparks, a \#1 New York Times bestselling author, could also have exhibited the sincerity dimension with his chosen characters in his books such as 'The Notebook', Three Weeks with My Brother' and 'A Walk to Remember.' His books have been acclaimed to convey a great deal of sincerity through the inflection of tone. The Bookhaven describes him as a person who 'writes with such passion and sincerity that one can't help but be moved by his honesty.'

The official website of Sue Monk Kidd aligns itself closely to the sophisticated dimension but also reveals that it has an element of sincerity. As the winner of numerous awards including the 2005 Quill Award for General Fiction, Sue's novel, The Mermaid Chair reached the \#1 spot on the New York Times bestseller list soon after publication and remained on the list for six months and this novel is being translated into 20 languages and produced as a television movie. Rooted in contemplative spirituality, her books recount her intense and vivid spiritual transformation. Sue's sophisticated nature could be attributed to her spirituality after deeply studing classical western spirituality, philosophy, depth psychology and mythology and reading voluminous amounts of literary fiction. No wonder, her first book was a spiritual memoir describing her advent into contemplative Christian spirituality: God's Joyful Surprise. On the other hand, this author also tells her story with such grace and sincerity by personally and passionately telling about her own unexpected journey into feminine spirituality. Therefore it could be a strategy to milk the advantages of both of these dimensions she purports to associate with.

Tom Clancy and Dan Brown's websites loosely associate themselves with the ruggedness dimension. This implies that the websites are not strongly communicating this dimension. However a quick look at the websites reveal that these authors somewhat try to communicate this dimension in some way. On his rugged nature, Clancy as a bestselling author has established himself as an undisputed master at blending exceptional realism and authenticity, intricate plotting, and razor-sharp suspense by writing on wars. Tom Clancy's books are not only excellent fodder for movies but have also proven to be well suited for games like Rainbow Six and Politika and the Power Play Series. Relying on a rugged terrain, ancient temples, bandit lairs, and murderous caverns, his games also help players to explore a vast fantasy $3 \mathrm{D}$ world. His movies such as Shoot to Kill were acted in rugged mountains of the Pacific Northwest, USA. All these in a way could contribute to his rugged nature. On the other hand, Dan Brown is the author of numerous \#1 bestsellers including 'Digital Fortress', 'Angels \& Demons' and 'Deception Point' and has been named as one of the World's 100 most Influential People by TIME Magazine. His acclaimed thriller novel, 'The Da Vinci Code' which has become one of the most widely read books of all time and describes rugged locations in England, Scotland and a trail. His rugged nature may in part have influenced writings.

This preliminary study has explored some author's brand personality positioning as communicated on their official websites by the use of a computer-aided context analysis tool. To a large extent, it has also helped us to demonstrate whether these authors are communicating these personalities clearly and distinctly. As revealed by the map, some authors in this study appear to create strong online brand personality for themselves by clear and distinct positioning. This is done by consciously communicating strong brand personality dimensions such as competence, sincerity, excitement and sophistication. Others seem either not to position themselves clearly. Thus, a plausible explanation of this is that, the content analysis dictionary that we constructed has adequately captured the creative meanings embedded in these websites. However, given the unrepresentative nature of the sample selected, it is not reasonable to claim that these five groupings reflect the range or distribution of meaning used in brand personality communication.

\section{Limitations of the study}

As content analysts are acutely aware of the dangers of generalizing from co-occurrence of words to assertions of relations among words existing within specific sentences (Robert, 1989), we never sought to generalise to all authors. Our major intention was to investigate the suitability of a research approach and research instruments. In this way, the websites used in this analysis were chosen to illustrate this phenomenon. This we achieved without a wide representative sample.

We are aware of the somewhat controversial nature of using content analysis software as an analytical tool. As with all computer-aided tools, this software is not a 'fool-proof'; and comes with its own challenges. This is most noteworthy when it comes to the construction of the dictionary. We believe that we were very fastidious in our approach to develop this dictionary, drawing from the expertise of several independent reviewers using several independent sources. We also painstakingly tested our instrument in two pilot studies, one of which was presented in a peer-reviewed forum. Although we believe that all the necessary measures were taken to avoid possible bias in creating this dictionary of brand personality terms, our understanding of the meaning of words and how they were selected to assemble the dictionary could be influenced by personal values, interpretations, experiences and knowledge. This is true of any instrument developed for any purpose. However, our pilot studies give us reason to believe that our instrument had both content and construct validity.

This tool only helped us to formally analyse text. However, visual or graphical images also represent cues and may convey strong multiple meanings to the web site visitors. For instance, the websites of Patricia Cornwell and J.K. Rowling were full of macromedia flashes thus making it difficult to download the text hence their exclusion. In this study, only text information was analysed, and therefore it is possible that the entire brand image may not be truly 
examined. This could impact on the portrayed brand personalities of these investigated websites.

\section{Research implications for content analysts, researchers and communication experts}

Though there has been many and varied potential benefits of using content analysis, the manual application of this research technique has traditionally made its use potentially unreliable and tedious. Computer-aided analysis can minimize both problems. Removing the human element in coding maximizes reliability, while the ability to scan text into a computer and have it analyzed in a matter of minutes removes much of the time and tedium of content analysis. Hence content analysts, scholars and marketing communication experts should be able to analyze more of a naturally occurring marketing text such as advertisements, corporate annual reports, focus group transcripts, newspapers and magazine publicity and so on with much less difficulty.

The brand personality communication application reported in this paper further illustrates how computers can read as well as count (Kabanoff, 1996) and how content analysis is fundamental to communication research. Similar word frequency analysis of other kinds of written text can make a major contribution to our understanding of a range of marketing practices and provide new insights into marketing communication. As part of the efforts of researchers to achieve a necessary level of scientific rigour in marketing communication, it is our firm believe that this is an optimal approach to conduct sophisticated content analysis by offering benefits in terms of cost, flexibility, and reliability and at the same time maintaining satisfactory levels of validity.

Lastly, but no mean least, one of the seemingly pioneering roles of this study has been the introduction and demonstration of the ability and advantages of combining content and correspondence analyses in evaluating websites. For instance, the correspondence analysis as exemplified here empowers all website managers to visualize the brand personality of their organizations' websites relative to their competitors, as well as relative to benchmarks at a very low cost. In today's fiercely competitive business environment, this combination of techniques affords organisations the ability to assess how their brand is positioned online, and how they are mirroring themselves in the minds of their stakeholders. Moreover, for the layman, interpretation of correspondence analysis maps is easier and more accurate than before. Compared to other outputs generated by many other statistical tools and procedures, these easy to interpret maps may aid brand managers in making faster, better informed decisions.

\section{Further research directions}

The trend in content analysis is toward increasingly employing computerised management of text. This evolution has been welcomed as an important development with the potential to improve the rigour of analysis. However, this study has focused on the meaning in part of brand personality communication in the online environment. To fully understand the communication dynamics, additional research is warranted in the examination of how brand personality perceptions of authors are formed in the online environment. To what extent are people influenced by website communication rather than advertising and other media portrayals? Content analysis of textual information on the web could also be compared with other communication media such as publisher's blurbs, reviews, commentaries, press reports and releases, and broadcast and print advertising in order to determine the extent to which authors, publishers, marketers and advertisers communicate consistent brand personality messages across all media. These relationships could be compared with stakeholderbased perceptions of brand personality. Subsequently, the techniques described here can aid longitudinal research on content analysis, so that the effect of online brand communication on other variables, such as press coverage, and of course other stakeholder perceptions, can be tracked over time and conclusions drawn accordingly. This study provides a preliminary outlook on what is communicated online, but it does not directly examine the impact of brand personality on the authors' websites. It could be interesting to study the effect of communicating a certain brand personality on the author's website performance. Future research could longitudinally track this overtime

\section{References}

Aaker, J. L. 1997. 'Dimensions of Brand Personality', Journal of Marketing Research, 34(3):347-356

Aaker, J. L. 1997. 'Dimensions of brand personality', Journal of Marketing Research, 34(3): 347-356.

Aaker, J. L., Benet-Martinez, V. \& Garolera, J. 2001. 'Consumption symbols as carriers of culture: A study of Japanese and Spanish brand personality constructs', Journal of Personality and Social Psychology, 81(3):492-508.

Abrahamson, P. R. \& Mechanic, M. B. 1983. 'Sex and the media: Three decades of best-selling books and major motion pictures', Archives of Sexual Behaviour, 12(3):185206.

Auchincloss, L. 2005. Writers and personality. Columbia, SC: University of South Carolina Press.

Bendixen, M. T. 1995. 'Composing perceptual mapping using chi-squared trees analysis and correspondence analysis', Journal of Marketing Management, 11(6): 571581.

Berelson, B.1952. Content analysis in communication research. Glencoe, Ill: Free Press.

Berthon, P., Leyland, P., Berthon, J-P., Crowther, C., Bruwer, L., Lyall, P. \& Money, A. 1997. 'Mapping the marketspace: Evaluating industry web sites using correspondence analysis', Journal of Strategic Marketing, 5(4): 233-242.

Biel, A. L. 1993. 'Converting image into equity'. In Aaker, D. A. \& Biel, A.L. (Eds.). Brand equity advertising. Mahwah, NJ: Lawrence Erlbaum Associates, p.p.67-83. 
Boyle, J. S. 1994. 'Style of ethnography'. In Morse J.M. (Ed.). Critical issues in qualitative research methods. Thousand Oaks, CA: Sage Publications, p.p.159-185.

Brown S. 2004. 'Writing marketing: The clause that refreshes', Journal of Marketing Management, 20(3-4):321342.

Bryman, A. \& Bell, E. 2003. Business research methods. New York, NY: Oxford University Press.

Cockburn, C. 1972. Bestseller: The books that everyone read, 1900-1939. London: Sidgwick \& Jackson.

Coles, C. D. \& Shamp, J. M. 1984. 'Some sexual personality, and demographic characteristics of women readers of erotic romances', Archives of Sexual Behavior, 13(3):187- 209.

Cooper, D. R. \& Schindler, P. S. 2003. Business research methods. New York: International Edition, McGraw-Hill.

Davies, G., Rosa, C., da Silva, R.V. \& Stuart, R. 2001. 'The personification metaphor as a measurement approach for corporate reputation', Corporate Reputation Review, 4(2):113-127.

Dowling, G. R.1980. 'Information content in U. S. and Australian television advertising', Journal of Marketing, 44(4):34-37.

Dowling, G. R. \& Kabanoff, B. 1996. 'Computer-aided content analysis: What do 240 advertising slogans have in common?' Marketing Letters, 7(1):63-75.

Erdener, C. \& Dunn, C.P. 1990. 'Content analysis'. In Huff, A.S. (Ed.). Mapping strategic thought. Chichester: Wiley Publishers.

Ferrandi, J. M., Valette-Florence, P. \& Fine-Falcy, S. 2000. 'Aaker's Brand Personality Scale in a French context: A replication and preliminary test of its validity', Developments in Marketing Science, 23:7-13.

Fournier, S. 1998. 'Consumer and their brands: developing relationship theory in consumer research', Journal of Consumer Research, 24(4):343-373.

Foster, D. W. 1996. 'Primary culprit: An analysis of a novel of politics,' New York Magazine, 26/02/96: 50-57.

Gottschalk, L. A. 1997. 'The unobtrusive measurement of psychological states and traits'. In Roberts, C.W. (Ed.). Text analysis for the social sciences: Methods for drawing inferences from texts and transcripts. Mahwah, NJ: Lawrence Erlbaum Associates, p.p.117-130.

Greenacre, M. J. 1984. Theory and applications of correspondence analysis. London, UK:

Academic Press.
Green, S. 1980. 'Best sellers'. In Turner, M. I. (Ed.). Handbook of American popular culture, Vol. 2. Westport, CT: Greenwood Press.

Gross, B. L. \& Sheth, J. N. 1989. 'Time-oriented advertising: A content analysis of United States magazine advertising, 1890-1988', Journal of Marketing, 53:76-83.

Hair, J. F., Anderson, R.E., Tatham, R.L. \& Black, W.C. 1998. Multivariate data analysis ( ${ }^{\text {rd }}$ Int. Edition). Upper Saddle River, NJ: Prentice Hall.

Hart, J. D. 1950. The popular book: A history of America's literary taste. New York, NY: Oxford University Press.

Harvey, J. 1953. 'The content characteristics of best-selling novels', The Public Opinion Quarterly, 17(1):91-114.

Hoffman, D. L. \& Franke, G. R. 1986. 'Correspondence analysis: Graphical representation of categorical data in marketing research,' Journal of Marketing Research, 23(3):213-227.

Hogan, R. 1991. 'Personality and personality measurement'. In Dunnette, M.D. \& Hough, L. M. (Ed.). Handbook of industrial psychology. ( $2^{\text {nd }}$ Edition). Palo Alto, CA: Consulting Psychologists Press.

Inman, J. J., Venkatesh, S. \& Ferraro, R. 2004. 'The roles of channel-category associations and geodemographics in channel patronage,' Journal of Marketing, 68(2):51-71.

Kabanoff, B.1996. 'Computers can read as well as count: How computer-aided text analysis can benefit organizational research'. In Cooper, C. L. \& Rousseau, D.M. (Eds.). Trends in organizational behavior. Chichester: Wiley Publishers, p.p. 1-21.

Kassarjian, H. H. 1977. 'Content analysis in consumer research', Journal of Consumer Research, 4:8-18.

Kolbe, R. H. \& Albanese, P. J. 1996. 'Man to man: A content analysis of sole-male images in male-audience magazines', Journal of Advertising, 25(4):1-20.

Kolbe, R. H. \& Burnett, M. S. 1991. 'Content-analysis research: An examination of application with directives for improving research reliability and objective', Journal of Consumer Research, 18(2):243-250.

Krippendorf, K. 2004. Content analysis: An introduction to its methodology. $2^{\text {nd }}$ Edition. Thousand Oaks, CA: Sage Publications.

Lebart, L., Salem, A. \& Berry, L. 1998. Multivariate descriptive statistical analysis: Correspondence analysis and related techniques for large matrices. New York, NY: John Wiley \& Sons.

Maclaran, P. \& Catterall, M. 2002. 'Analysing qualitative data: Computer software and the market research practitioner,' Qualitative Market Research: An International Journal, 5(1): 28-39. 
Marshall, C. \& Rossman, G. B. 1999. Designing qualitative research. $3^{\text {rd }}$ Edition. Thousand Oaks, CA: Sage Publications.

Miles, M. B. \& Huberman, M. A. 1994. Qualitative data analysis: A source book of new methods. $2^{\text {nd }}$ Edition. Thousand Oaks, CA: Sage.

Mosteller, F. \& Wallace, D. L. 1964. Inference and disputed authorship: The Federalist. Reading, MA: Addison-Wesley.

Mullins, L. S. \& Kopelman, R. E. 1984. 'The best seller as an indicator of societal narcissism: Is there a trend?' The Public Opinion Quarterly, 48(4):720-730.

Neuman, W. L. 2003. Social research methods: Qualitative and quantitative approaches. 5th Edition. Boston, MA: Allyn and Bacon.

O’Brien, T. W. 1993. 'Correspondence analysis', Marketing Research, 5(4): 54-56.

Opoku, R. A. 2005. 'Communication of brand personality by some top business schools online'. Thesis for the degree Licentiate of Philosophy, Department of Business Administration and Social Science, Luleå University of Technology, Luleå.

Péladeau, N. 2003. WordStat: Content analysis module for SIMSTAT. Montreal: Provalis Research.

Punj, G. \& Stewart, D.W. 1983. 'Cluster analysis in marketing research: Review and suggestions for application', Journal of Marketing Research, 20(2):134-148.

Resnik, A. \& Stern, B. L. 1977. 'An analysis of information content in television advertising', Journal of Marketing, 41(1):50-53.

Romano, N. C., Donovan, C., Chen, H. \& Nunamaker, J. F. 2003. 'A methodology for analyzing web-based qualitative data,' Journal of Management Information Systems, 19(4): 213-246.

Richards, L. \& Richards, T. 1987. 'Qualitative data analysis: Can computers do it?' Australian and New Zealand Journal of Sociology, 23(1):23-35.

Robert, C. W. 1989. 'Other than counting words. A linguistic approach to content analysis, Social Forces, 68(1):147-177.

Stemler, S. 2001. 'An overview of content analysis', Practical Assessment, Research \& Evaluation, 7(17). [online] URL:

http://PAREonline.net/getvn.asp?v=7\&n=17.Accessed

23/3/2006.

Stone, P. J., Dunphy, D.C., Smith, M.S. \& Ogilvie, D.M. 1966. The general inquirer: A computer approach to content analysis. Cambridge, MA: MIT Press.

Stone, P. J. 1997. 'Thematic text analysis: New agendas for analyzing text content'. In Roberts, C.W. (Ed.). Text analysis for the social sciences: Methods for drawing inferences from texts and transcripts. Mahwah, NJ: Lawrence Erlbaum Associates, p.p.35-54.

Sutherland, J. 1981. Bestsellers: Popular fiction of the 1970’s. London: Routledge \& Kegan Paul.

Tesch, R. 1990. Qualitative research: Analysis, types and software tools. New York, NY: The Falmer Press.

Tesch R. 1991. 'Introduction', Qualitative Sociology, 14(3): 225-243.

Tse, D. K., Belk, R.W. \& Zhou, N. 1989. 'Becoming a consumer society: A longitudinal and cross-cultural content analysis of print ads from Hong Kong, the People's Republic of China, and Taiwan', The Journal of Consumer Research, 15(4):457-472.

Weber, R. P. 1985. Basic content analysis. Beverly Hills, CA: Sage.

Weber, R. P. 1988. Basic content analysis. Beverley Hills, CA: Sage University Paper Series on Quantitative Applications in the Social Sciences, Series 07-049.

Wolfe, R. 1991. 'The use of content analysis to assess corporate responsibility', Research in Corporate Social Performance and Policy, 12: 281-307.

Wolfe, R. A., Gephart, R. P. \& Johnson, T. E. 1993. 'Computer-facilitated qualitative data analysis: Potential contributions to management research,' Journal of Management, 19(3): 637-660. 
Appendix I: EIGENVALUES

$\begin{array}{lcc}\text { Eigenvalues } & \text { Percentages } & \text { Cumulative Percent } \\ 0,080 & 52,964 & 52,964 \\ 0,043 & 28,081 & 81,046 \\ 0,021 & 13,868 & 94,913\end{array}$

VARIABLES COORDINATES

$\begin{array}{lccc}\text { Item } & \text { Axes 1 } & \text { Axes 2 } & \text { Axes 3 } \\ \text { D. Brown } & -0,600 & 1,591 & 1,211 \\ \text { D.Steel } & 0,062 & 0,290 & -1,326 \\ \text { E. Kostova } & 0,285 & -0,296 & -0,285 \\ \text { J. Grisham } & -2,235 & -1,763 & -0,461 \\ \text { J. Patterson } & -0,414 & 0,088 & -2,029 \\ \text { M. Albom } & 0,815 & -0,251 & -0,749 \\ \text { N. Sparks } & 0,730 & -1,097 & 1,357 \\ \text { S.King } & -1,148 & -1,203 & 0,259 \\ \text { S.M.Kidd } & 1,475 & 0,210 & -0,195 \\ \text { T.Clancy } & -1,135 & 1,391 & -0,168\end{array}$

WORDS/CATEGORIES COORDINATES

$\begin{array}{lccr}\text { Item. } & \text { Axes 1 } & \text { Axes 2 } & \text { Axes 3 } \\ \text { COMPETENCE } & -1,482 & -1,289 & 0,418 \\ \text { EXCITEMENT } & -0,424 & 0,332 & -1,513 \\ \text { RUGGEDNESS } & -0,905 & 2,346 & 1,346 \\ \text { SINCERITY } & 0,904 & -0,393 & 0,620 \\ \text { SOPHISTICATION } & 1,297 & 0,416 & -0,894\end{array}$

